\title{
Discursive conflicts in news media and the suspension of a government-led test of English in Korea
}

\author{
Dongil Shin ${ }^{{ }^{*}}$ (D) and Eunhae $\mathrm{Cho}^{2}$ (1)
}

\author{
* Correspondence: shin@cau.ac.kr \\ 'Department of English Language \\ and Literature, Chung-Ang \\ University, 221 Hukeok-dong, Seoul \\ 156-756, South Korea \\ Full list of author information is \\ available at the end of the article
}

\begin{abstract}
Drawing on critical discourse analysis methodologies, this study examines the discursive conflicts and strategies employed by newspaper media surrounding the National English Ability Test (NEAT) in Korea. NEAT was reported to cause severe competition among young learners of English and lacked public support. Discursive conflicts over whether NEAT would be legitimized flourished in the media. In this study, the discursive practices adopted by both proponents and opponents of NEAT in two leading Korean newspapers of different political orientations-Chosun Ilbo and Hankyoreh - were analyzed from 2006 to 2016. Over this decade, there were three periods of transformation: creation, expansion, and extinction. During the creation period, the discursive conflict focused on the TOEFL crisis in Korea, expansion on the implementation of NEAT, and extinction on its abolition. From creation to abolition, there were competing rationales for developing, suspending, or abolishing NEAT. This study investigated the underlying orientations (neoliberal and evaluative state) of the two newspapers and found that they examined the pros and cons of using the test. Moreover, the government's implementation of high-stakes testing and its attempt to reward those who complied and to curb the private education sector stresses market-friendly state interaction, which accordingly perpetuates neoliberal conditions.
\end{abstract}

Keywords: Critical discourse analysis, Discursive conflicts, High-stakes testing, National English Ability Test (NEAT), Neoliberalism, Evaluative state

\section{Introduction}

In April 2007, excessive demand for the Test of English as a Foreign Language (TOEFL) caused the so-called TOEFL crisis in Korea. The administrator of TOEFL-iBT was unable to provide sufficient Internet-connected computers to meet the needs of Korean testtakers. When the Educational Testing Service (ETS) posted the slots for the subsequent test date, the seats were immediately taken and the spike in traffic and phone calls resulted in registration failure. The Korean media reported on this crisis, calling attention to the chronic English fever in Korea. Shin $(2012,2019)$ conducted critical discourse analysis on the TOEFL crisis in Korean newspapers and discovered that the discourse was being articulated in terms of market mechanisms and social utilities. For example, TOEFL-iBT was

(c) The Author(s). 2020 Open Access This article is licensed under a Creative Commons Attribution 4.0 International License, which permits use, sharing, adaptation, distribution and reproduction in any medium or format, as long as you give appropriate credit to the original author(s) and the source, provide a link to the Creative Commons licence, and indicate if changes were made. The images or other third party material in this article are included in the article's Creative Commons licence, unless indicated otherwise in a credit line to the material. If material is not included in the article's Creative Commons licence and your intended use is not permitted by statutory regulation or exceeds the permitted use, you will need to obtain permission directly from the copyright holder. To view a copy of this licence, visit http://creativecommons.org/licenses/by/4.0/. 
justified based on the utilitarian perspective. The demand for a standardized and externally developed test of English proficiency was required not only to gain credibility in the global market but also to demonstrate competitiveness compared to locally developed tests (Im, Cheng, \& Shin, 2020).

A government-led English proficiency test, however, had previously been discussed and initiated in Korea, before the TOEFL crisis. In 2006, as the CSAT (College Scholastic Ability Test) and school curriculum were perceived not to have adequately fostered the productive skills of English speaking and writing, government officials and experts in language testing considered the development of a new homegrown test to measure all "four skills of English." The TOEFL crisis afterwards fueled the impetus toward the implementation of such a test, providing a socio-economic and political rationale for it; for example, to decrease the demand for English proficiency tests, the government abolished the use of English proficiency test scores (e.g., TOEFL) as criteria for elite school admission. The clamor to develop a homegrown standardized English proficiency test to ensure global competence escalated, with the criticism levied that Koreans spent more than 10 million dollars annually on TOEFL/TOEIC application fees. TOEFL-driven policies were argued to be the problem and to be resolvable by implementing a local, indigenous English test, or "Korean version of TOEFL."

The Korean Ministry of Education intervened in the volatile market after serious consideration to the state of English language testing in various contexts in Korea. In 2008, the presidential transition committee officially announced the development of a new English proficiency test, tentatively called "Korean TOEFL": NEAT (the National English Ability Test). It was to be implemented at three levels: level 1 targeted adults and college students, while levels 2 and 3 targeted high school students and were geared to fit with the college entrance examination system. It was also announced that whether or not NEAT would replace English in the CSAT would be decided in 2012. The existing college entrance exam only assessed listening and reading skills, while NEAT would test all four commonly recognized skills of English proficiency, including speaking and writing.

However, the media heightened the negative effects of its implementation through, for example, private education expenditure, scoring credibility, or insufficient equipment. Politicians' apprehension about public opinions, in addition to the flagging media coverage, led to the termination of the full administration of the test. NEAT was not substituted for CSAT in college entrance exams until 2013, and this state-administered NEAT was suspended by the subsequent government in 2014. Then, levels 2 and 3 were abolished in 2014, along with level 1 in 2015, due to public awareness and practicality issues (Lee \& Lee, 2016; Whitehead, 2016). It was reported that "practicality issues, especially the economic decisions and social perceptions" (Lee \& Lee, 2016, p. 831), or "a split in support" (Whitehead, 2016, p. 124) for NEAT's implementation (which media coverage heightened during the trial stage), were not duly weighed and managed. Although there were voices championing NEAT for its positive washback effect on the public, anticipating development of receptive as well as productive skills, the media failed to effectively cover public opinion, as the test was already set to be abolished. The expense of test development over approximately 6 years totaled 40 million US dollars, and those who had initiated and developed NEAT were absolved from their responsibilities. Their participation and subsequently their exclusion were 
justified solely in the test-as-policy-making context, driven by government voices, and mostly battled in the media, which legitimized or challenged different stakeholders' rationales.

As one of the most important sites in which test-driven policies are articulated, media reportage plays a vital role in agenda setting, serving as an arena for different sociopolitical discourses in which stakeholders' rationales are reflected. A newspaper's text and images demonstrate the position it takes but also constitute the discourse used to justify and maintain dominance in the arena. Discourses are legitimized or challenged against the status quo, putting the discourse of social practice into action (Fairclough, 1992). Drawing on critical discourse analysis methodology, this study aims to examine the discursive construction and conflicts employed by newspaper media surrounding NEAT. It will illustrate how newspapers employed specific discursive strategies to represent the problems and solutions of the TOEFL crisis and NEAT's implementation and abolition, from neoliberal and evaluative state perspectives.

\section{High-stakes testing and language policy}

A close correspondence exists between high-stakes testing and policy implementation. Language tests play a determining role in specifying what official language to adopt, the hours and methods to be invested, and the mandate and rationale for teaching languages (Shohamy, 2001, p. 105). It is not merely through the declared policy statements but rather through the multiple types of social mechanism that real policies are perpetuated (Shohamy, 2006, p. 45). Language testing policy is de facto language policy, as those in authority use the device of language tests, despite the detrimental effects of tests on students' lives and teachers' reputations (Shohamy, 2001).

Language testing has been implicitly or explicitly used as a political means to achieve ostensive outcomes (McNamara \& Roever, 2006; Menken, 2008; Shohamy, 2001, 2003, 2006, 2007). However, few policymakers patiently await the intended result. They rarely invest effort in innovative curriculums, textbooks, or teacher education before rushing to link high-stakes testing with policy implementation. Even worse, despite common belief that testing is undesirable, the practice of testing is maintained and even enforced since testing practice is believed to encourage stakeholders, control knowledge, and guarantee the intended success of policy implementation (Shohamy, 2001, 2007).

Menken (2008) criticized the misuse of high-stakes testing with reference to the tradition of intelligence quotient testing, which she claimed was originally used as a political tool to marginalize ethnic minorities and immigrants. Although Cheng and Curtis (2004) asserted "the washback effects [of high-stakes testing] are positive or negative," (p. 11), Menken (2008, p. 401) cast doubt upon its value. This is because once the testing power of decision-making increases, the scope of the curriculum is narrowed. Teachers voluntarily educate themselves in the contents covered by high-stakes testing and only those contents are covered in class, eventually leading to a culture of teaching-to-the-test (Madaus \& Russell 2010; Menken, 2008). In the USA, when high-stakes testing was conducted under the No Child Left Behind (NCLB) policy, the teaching-to-the-test phenomenon spread quickly (Menken, 2008). Madaus and Russell (2010, pp. 26-27) also insisted that while testing facilitates learning and teaching, it tends to lead to a situation where instruction neglects characteristics or subjects not covered in tests. 
Although high-stakes language testing has been a strong motive in establishing language policy in local contexts like schools or in national units, the related purposes of language testing and policy-making have hardly been elucidated. The public tends to view the (language) testing imposed upon them as value-free and neutral (Menken, 2008, p. 410) and focus on the "hidden competence" to be explored individually and on success stories in discussing how to prepare for the test (Park, 2010). Similar discussion can be conducted regarding the intent and effect of NEAT, which the Korean government top-downed in haste. When the expenditure invested and the duration of investment are considered, the soundness of the socio-political role played in the development of NEAT is questionable.

\section{Discourse of language policy in the media}

In the media, discourse is often understood as the social activity of meaning-making through language use (van Dijk, 2009). Discourse is neither a neutral nor an objective medium but something that is constructed within society. An ideology or belief that is taken for granted can also construct discourse, exercising a dialectic influence thereon. Therefore, discourse contributes to reproducing, and even transforming, a society. It does not simply deliver a message but holds power in representing to the readers a certain social action. Borrowing from Foucault (1981), Fairclough (2003) termed these mediating practices "orders of discourse."

Language test implementers often adopt media discourse as a mechanism for the different stages of language policy and planning, because the media influence public cognition in overt and implicit ways (van Dijk, 1998). However, the public may also resist the dominant discourse and protest against manipulations. Both dominant and minor (alternative) orders of discourse coexist, sometimes competing with and replacing one another. Multiple and contradictory discourses co-inhabit and co-influence intertextually-particularly through articulation-and those that gain dominance eventually exercise power over group members in the form of hegemony (Olssen, Codd, \& O'Neill, 2004). Therefore, newspapers, as a representative of mass media, become the loci of ideological production (DiGiacomo, 1999, p. 105). Newspapers adopt editorial positions on contemporary issues, and function as the apparatus of the powerful when language policy and planning are enforced. It is through the media that the battles for power and control, visibility, and voice occur (Shohamy, 2006, p. 55). Discursive struggles are particularly prominent in the implementation of high-stakes testing-driven policy. To produce a policy text entails dynamic, multiple, and competing discourses that move from conflict to consensus (Wodak, 2000), and consensus can be understood as gaining predominance in the hegemonic struggle.

There are previous studies on the role of the media as a site of discursive struggle in the field of language policy and planning (Ball, 1993; Crawford, 2004; Johnson, 2005; McDonald, 2014). For example, Crawford (2004) analyzed the pattern of media coverage in passing California Proposition 227 in 1998. Proposition 227 sought to end bilingual education and the use of languages other than English for instruction in public schools. It was found that while national publications enthusiastically heralded Englishonly instruction, advocates of bilingual education adopted a reactive approach, but little coverage was given to the success of bilingual programs. Therefore, the press coverage became a self-reinforcing cycle: journalists disseminated negative messages, which 
helped to shape public attitudes, thus leading voters and politicians to adopt antibilingual policies, and in turn influencing journalists to disseminate more negative messages about bilingual education (Crawford, 2004, p. 730). Johnson (2005) analyzed the rhetoric used in two periodicals surrounding the Arizona Proposition 203 campaign. Multiple negative metaphors were used, and the war metaphor was strategically implemented to impair the credibility of bilingual education programs. Bilingual education was seen as a threat, while advocates of Proposition 203 were characterized as a "heroic" military force sent to combat "evil" bilingual programs.

Although a few studies on the role of media in language policy and planning were found, there remains a dearth of research on media discourse and high-stakes testing policies. Based on the print media's function in constructing, reproducing, and challenging highstakes test-based language policy, this study describes how a newly developed test in Korea functioned as a genetic mechanism for conducting language testing policy in the media.

\section{Research method}

\section{Data collection}

Much research has focused on social issues as discursive accumulation. Taking the print media as an ideological battleground (J. Lee, 2010), this study examined competing discourses in NEAT-related newspaper articles. Two leading Korean newspapers of different political orientation-Chosun Ilbo and Hankyoreh-were selected. Chosun Ilbo is a conservative daily, while Hankyoreh is known to have a progressive ideological orientation. Each newspaper was expected to adopt its own position, values, and core statements.

Since the development and policy-driven administration of NEAT were to be analyzed contingent on the TOEFL crisis, the NEAT discourse was deemed to have begun on 4 April 2007 when the media critically reported news of frustrated TOEFL testtakers. The expansion period began with former President Lee's administration in 2008. Upon his inauguration, the new government announced several agendas on English language education, including NEAT expansion projects. It was reported that the newly developed test could replace the conventional CSAT English test and that the substitution would be determined in 2012. However, faced with a strong public backlash, the committee had to revise its plan. A pilot test arranged for 17 February 2012 was cancelled without notice, and many assumed technological instability, arousing suspicions about the test implementation. The extinction period of the NEAT discourse followed from the end of the Lee administration until February 2013. It was reported that NEAT would not replace CSAT, and ultimately, level 2 was abolished in 2014 and level 3 in 2015. This study focuses on the period from 2007 to 2015.

Three keywords were used to collect related newspaper articles: TOEFL crisis, NEAT, and National English Ability Test. Articles on society, education, opinion, and interviews were sourced from the newspaper database Eye-surfer. Commercials and general topics on English were all excluded. A total of 84 newspaper articles were collected and analyzed, and Table 1 shows the distribution of the articles over the three periods.

\section{Analysis}

Critical discourse analysis is a methodology that investigates the interplay between abstract structures and concrete events, along with the mediating practices that 
Table 1 Distribution of articles in the three periods

\begin{tabular}{lll}
\hline Period & Number of articles & \\
\cline { 2 - 3 } & Chosun Ilbo & Hankyoreh \\
\hline Creation (April 2007-May 2007) & 10 & 7 \\
Expansion (June 2007-March 2013) & 26 & 26 \\
Extinction (April 2013-December 2015) & 12 & 3 \\
Total (84) & 48 & 36 \\
\hline
\end{tabular}

contribute to reproducing the existing regime. Concrete events in this study refer to the newspaper texts, whereas abstract structures comprise the ideological backgrounds that justify and rationalize the meaning of NEAT-related discourses. This study adopted Fairclough's (1992) critical discourse analysis as a methodological framework, which is considered useful for the analysis of media discourses (Blackledge, 2005; Lin, 2014). It assumes that discursive and social change are closely related and that the dynamic state of discursive struggles can be demonstrated in different periods of the NEAT discourse.

This study comprises a three-tier analysis: descriptions of text arrangement, interpretation of discursive practice, and explanation of socio-political practice. In the description phase, the conflicting positions of textual display were summarized, whereas the linguistics analyses were not fully reported in this study. Textual analysis usually draws upon linguistic theory of systematic functional linguistics (Halliday \& Matthiessen, 2014), in which texts are taken as a manifestation of power from the selection and exclusion process. It pays attention to semiotic and grammatical relations between words, sentences, and paragraphs. When certain discourses are distributed and interpreted in society, dispersed texts develop mutual relationships, or become inter-textualized into different layers of discourse. Discursive strategies include positive self-presentation and negative other-presentation (Oktar, 2001), as well as articulation, disarticulation, and re-articulation (Fairclough, 1992). Lastly, the discursive process and wider social process regarding how discrepancies are perpetuated in the socio-cultural dimension are explained. This approach understands ideology in terms of the social representations shared by a group, which justifies the structured order (Fairclough, 2003).

\section{Results and discussion}

\section{Description of text arrangement}

Table 2 summarizes how the texts on NEAT were constructed. Different positions were adopted to describe the TOEFL crisis (problem and solution) in the period of creation. During the implementation and abolition of NEAT, newspaper texts could be divided into two frames: supporting and opposing.

\section{Creation phase: problems and solutions of the TOEFL crisis Problems}

The TOEFL crisis was diagnosed in terms of problem, obstacle, dispute, or dilemma, which were framed as "crises" and largely described in terms of (1) supply and demand, (2) inconvenience, and (3) foreign currency outflow. It was often reported that supply 
Table 2 Description of how NEAT texts were selected and positioned

\begin{tabular}{clll}
\hline \multicolumn{5}{c}{ Stages } & & \\
\cline { 2 - 4 } Positioning & Creation (with TOEFL crisis) & Expansion (NEAT implementation) & Extinction (NEAT abolition) \\
Agenda & 1. Supply and demand & Supporting & Supporting \\
& 2. Inconvenience & 2. State-led accountability & 1. Domestic purposes only \\
& 3. Foreign currency outflow & 3. Technological efficiency & 2. Private education \\
\cline { 2 - 4 } Positioning & Solution & 3. "Easy CSAT" \\
Agenda & 1. State intervention & 1. Private education & 4. Technical failure \\
& & expenditure & Opposing \\
& 2. Korean TOEFL with & 2. Teach-to-the-test & 1. (Back to) CSAT-prep \\
& official recognition & & English \\
\hline
\end{tabular}

did not meet demand. The competition for TOEFL-taking seats resulted in the breakdown of the Internet server, dubbed by newspapers the TOEFL crisis and arousing public opinion on chronic English learning fever in Korea.

Repetitive words appeared on the market mechanism, with explicit elaboration as follows: "The TOEFL crisis can be understood simply as a principle of demand and supply mechanism" (Won, 2007) and "The essence of this plight can be explained by the mismatch between supply and demand" (Y. Lee, 2007). Demand issues were well delivered by Chosun Ilbo using monetary vocabulary. For example, some people ordered vouchers for TOEFL-iBT test-taking and resold them for twice the amount, while others went on "expeditions for TOEFL" (N. Kim, 2007a; 2007b), or "took flight(s) to nearby countries such as Japan, Taiwan, the Philippines, and Hong Kong to take the test" (Hong, 2007).

The second problem was formulated as inconvenience. Since test-takers could register neither by Internet nor by telephone, inconvenience issues were often highlighted. Test-takers complained about ETS's unreliable test administration. For example, ETS unexpectedly cancelled a pre-registered TOEFL-iBT test (N. Kim, 2007b April 13) and accepted registration on abrupt submission ("Te-nun pang-chi-hal,", 2007; Chung, 2007; J.-H. Jeon, 2007; K. Kim \& W. Choi, 2007; Won, 2007). ETS remained silent about test-takers' complaints, with its reactions described as "arrogant" (N. Kim, 2007b) and "high-handed" (Kim, 2007b), and Korean test-takers described as "disappointed," "frustrated" (K. Kim \& W. Choi, 2007; "Te-nun pang-chi-hal,", 2007), and even "infuriated" (J.-H. Jeon, 2007; K. Kim \& W. Choi, 2007) by the inconvenience. Hankyoreh also emphasized the inconvenience faced by high school students.

The third problem was connected to the waste of foreign currency on foreign tests, such as TOEFL and TOEIC, leading to a solution discourse around the development of a "Korean version of TOEFL." The money spent on foreign tests was highlighted in Chosun Ilbo (Hong, 2007; Won, 2007): "Considering that the test fee for TOEFL is 150 thousand won, the ETS earns 16 billion won per year. However, ETS totally ignores our test-takers." The media also cited the number of students taking foreign tests, the cost of test registration fees, and the total amount of foreign currency outflowed to ETS. Therefore, the rationale for developing NEAT to 
reduce Korea's dependence on foreign tests was justified in the discourse on the TOEFL crisis.

\section{Solutions}

In response to the TOEFL crisis, solution discourses were formulated, relying on the ideas of (1) state intervention and (2) a Korean version of TOEFL. Two days after the TOEFL crisis, Chosun Ilbo proposed that the Korean government should establish an institute similar to ETS (Hong, 2007; J. Kim, 2007 April 13). Dubbing the situation the "TOEIC/TOEFL gale," where the whole nation is swarmed around TOEFL', state intervention was called for. It was also reported that a special bill on English Education Promotion had been submitted to the congress (J. Kim, 2007 April 14). To assess Koreans' English proficiency, a government-led standardized test was proposed in both newspapers to replace imported tests ("Te-nun pang-chi-hal,", 2007; Hong, 2007; J. Kim, 2007 April 14; K. Kim \& W. Lee, 2007). Although several homegrown tests were authorized by the Korean government in 2007, the media clamored for state intervention to produce a test with public recognition, equivalent to TOEFL on the global market ("Tenun pang-chi-hal,", 2007; Y. Lee, 2007; Won, 2007).

\section{Expansion phase: supporting and opposing the implementation of NEAT}

\section{Supporting}

NEAT, which was tentatively named the "Korean version of TOEFL," was now at the stage of development and pilot administration, and its proponents had formulated their claims in terms of (1) state-led accountability, (2) practical English learning, and (3) technological efficiency.

First, the proponents hoped for the best in state-led accountability. It was reported that the NEAT project would not fail if the government took initiative for its successful implementation. Hankyoreh proposed establishing the Korea English Proficiency Testing Foundation-a consortium comprising universities, the Korea Institute for Curriculum and Evaluation (KICE), and the Educational Broadcasting System (EBS) (H. Choi, 2007). Chosun Ilbo (Ahn, 2010a) reported that the Korean version TOEFL would be accepted in the college admission policy from 2013. In a brief article, it was reported that the government and KICE were now working on test development and that the Minister of Education would announce the policy and decide whether to replace the current English section of CSAT with the Korean version of TOEFL. Another Chosun Ilbo article (Ahn, 2010b) introduced the specifications of the new test, including its time limit, question types, and task characteristics, and emphasized that they were all based on the National Curriculum. It was also reported that the government should bear the burden of testing fees for lowincome students and that test prep materials should be distributed for free through EBS (Ryu, 2008).

Second, there was an optimistic view regarding NEAT's washback effect, with a report that NEAT would assess the full range of communicative language abilities, termed "practical English." While the conventional CSAT only assesses English reading and listening skills, NEAT's four skills (speaking, listening, writing, reading) were valuable and practical as "one body" (J.-B. Jeon, 2012a). Students preparing for NEAT would be able to express, write, and speak freely, as the related instruction would no longer adopt vocabulary 
memorization or drill exercises (Cho, 2011). Students were thus expected to "acquire comprehensive and integrated ability to use authentic English" (Cho, 2011). NEAT-driven "practical English" would restore public school education. The test contents would be based on the National Curriculum, and the difficulty of test items would be in accordance with secondary school textbooks (M. Choi, 2012). Public school teachers would be trained to teach NEAT English successfully in public school contexts: "since many incumbent teachers were trained for NEAT [...] people should not be swayed by the fear aroused by private education" (J.-B. Jeon, 2012a). It was often reported that students could prepare for practical English in NEAT, simply "by following teachers in public school classrooms," while private education was criticized for engaging in "fear-marketing" (M. Choi, 2012). As long as students studied school textbooks "diligently" (Cho, 2010; S. Kim, 2011), "in daily life" (S. Kim, 2011), and "in their own independent way" (J.-B. Jeon, 2012a), they could master the practical English of NEAT, without relying overly on private education (M. Choi, 2012).

Third, texts on technological efficiency were selected to support the implementation of NEAT. Unlike the TOEFL-iBT, which had suffered from a server breakdown, NEAT would triumph in its technological aspect. With the help of cloud-computing, a large number of students were expected to take the test simultaneously at testing venues. NEAT was "an innovative testing system built upon cloud computing, and integrating cutting-edge measurement theories and IT technologies" (KERIS, 2013, pp. 42-43). Therefore, once the test had settled and gained a reputation worldwide, it was expected to become Hyoja, or a money-making industry that greatly contributes to Korea's exporting business (Cha, 2013).

\section{Opposing}

Numerous texts opposing the implementation of NEAT were also published. Opponents often appealed to the burden on students, parents, and teachers in terms of private education expenditure and the teach-to-NEAT culture. NEAT was originally designed to reduce students' dependence on private tutoring and to strengthen public school education, but many worried that the NEAT-driven policy would have the totally opposite result, with students and parents turning to private academies, or hagwon (J. Lee, 2008; J. Lee \& M. Jeon, 2008). The rural-urban or rich-poor divide was another concern (J. Lee, 2011) along with the flourishing of private lessons for NEAT preparation. Parents were troubled by the possibility that students from well-off families would easily score better, as they would have more resources to improve English speaking and writing, mostly through private tutoring. It was often reported that private academies were moving fast to capitalize on parents' concerns, and many touted that their curriculum and textbooks had been adapted to NEAT English.

Moreover, details on the implementation reversed. Unlike CSAT, which is administered once a year, it was initially announced that NEAT would be held at least four times a year, but this was later reduced to twice. Moreover, whether NEAT would replace the English section of CSAT was not determined by 2013. These changes meant that students had to prepare for both high-stakes tests to be competitive for university admission. This "double whammy" (J.-B. Jeon, 2012b; J. Lee, 2011) was reiterated, and NEAT was specified as "another burden obligated through private tutoring" (J. Lee, 
2011). Teachers also questioned whether NEAT would reduce students' study burden or improve public school education. For example, M. Kim (2012) published a note from an anonymous public teacher in which a stark contrast was made between private and public education and which questioned public teachers trapped by inertia. The adjectives used for private education teachers were "sincere," "approachable," "attentive," "affable," and "with up-to-date information," while public school teachers were "insincere, " "cursory," and "killing class time" on the premise that students had already learned at private schools.

The doubts cast on public education disclosed and expedited early study abroad (ESA) issues. Both newspapers connected ESA-related problems with the coming administration of NEAT (Jin, 2012; J. Lee, 2011; Yoo, 2011). A headline in Chosun Ilbo from 4 October 2011 (Yoo, 2011) stated "ESA is on the Rise," with the subtitle "In four years, the transition toward practical English resulted in the increase of ESA students." In 2010, there was a 3.4\% increase in the number of ESAs over 2009, amounting to 17, 841. Hankyoreh specified 2009 as the first year of NEAT pilot testing (Jin, 2012).

Teach-to-NEAT was another reason for opposition to the test. It was argued that proponents of NEAT adopted an optimistic view of the "practical English" taught in English classes. However, the definition of practical English was vague; the test construct was often debated and criticized. It was questioned how a newly developed high-stakes test could resolve English-divide social issues (Jang, 2008). It was expected that enforced test reform would lead in the long run to teach-to-the-test (J. Lee, 2011; Yoo, 2009).

\section{Extinction phase: supporting and opposing the abolition of NEAT}

On 10 May 2013, with the inauguration of a new government, the Ministry of Education announced that NEAT would not replace the English section of the current stateadministered CSAT. This sudden change in policy meant that NEAT became extinct. The pros and cons of this abolition were discussed, and conflicts arose over whether the abolition of the test was justified.

\section{Supporting}

Texts supporting the abolition of NEAT made their case by characterizing it in four ways (1) for domestic purposes only, (2) ineffective for reducing cost of private education, (3) an easy version of the CSAT, and (4) a technical failure. Plans were underway to adopt NEAT as a substitute for contemporary English tests such as TOEIC, TOEFL, and the English section of the CSAT. However, NEAT scores were restricted to a domestic (Korean) context, and the dependence on imported tests was sustained. Chosun Ilbo (Y. Kim \& H. Kim, 2013) reported that students who wished to study abroad would not have to take NEAT. It was also reported that the implementation of NEAT would not reduce the cost of private education. The Ministry of Education rushed to have NEAT scores used as reference materials in university admissions, and this sudden change drove many students to private institutes or language courses overseas. Students were not expected to achieve the "practical" level of speaking and writing solely through public school education, and the private education market quickly responded to the change, as the lack of programs, teachers, and materials in public schools presented an obstacle to teaching for the new test. 
In the following year, when the government announced that NEAT would not replace the CSAT, a new ("easy") version of the CSAT emerged as an alternative solution to the bungled policy-driven NEAT. This literally meant that an easier version of the CSAT would be administered in a bid to reduce private education costs and to prevent young students from being over-competitive in English tests. The spotlight then moved to CSAT issues (e.g., difficulty level) and NEAT fell into oblivion. Furthermore, by the end of the expansion period, concerns arose over system instability. On 2 June 2013, computing errors occurred when marked answer sheets were not saved and the test had to be re-taken. It was noted that policymakers had recklessly pressed ahead with the new test, without securely implementing the Internet-based testing system. Technological efficiency was one of the main reasons NEAT's success had been promised. Now, NEAT was doomed to fail due to technological problems, thus replicating the previous TOEFL crisis.

\section{Opposing}

The views against the abolition of NEAT were formulated in terms of (1) the problematic back-to-CSAT-prep situation, (2) wasted budget, and (3) victimized students. One strong criticism was that the situation of CSAT prep had further deteriorated. Chosun Ilbo ("Han-kwuk-hyeng,", 2014; Ahn, 2014a; Y. Kim, 2014) presented the dichotomy between CSAT prep English and practical English. The abolition of NEAT was expected to restore English teaching to the CSAT prep, or old English education, in which only listening and reading were emphasized (Ahn, 2014b).

Furthermore, the wasted budget was frequently mentioned. Although the newspapers were inconsistent regarding the exact sum invested in NEAT, ranging from 37.1 billion won ("Han-kwuk-hyeng,", 2014; Ahn, 2014b), to 40 billion (Ahn, 2013), to 50 billion (Eum \& J. Kim, 2013), both newspapers criticized the government for wasting large sums. Hankyoreh, for example, criticized the wasted efforts and money with its subtitle "NEAT Never Implemented; Test Candidates Ridiculed; 50-billion-won Budget Wasted” (Eum \& J. Kim, 2013).

Students were often depicted as victims of the whims of the Ministry of Education ("Hankwuk-hyeng,", 2014). They were described as "laboratory animals" ("Han-kwuk-hyeng,", 2014) and those whose voices were never heard (H. Lee, 2013). Hankyoreh (Eum \& J. Kim, 2013) also reported that almost 70,000 candidates had prepared for the test in vain. It was noted that students, whose voices had not been collected in the public hearings, surveys, or any other form of public opinion, had become the biggest victims of the policy change.

\section{Interpretation of discursive practice}

Table 3 summarizes how the conflicting discourses of NEAT were constructed in each newspaper. Although scattered texts produce outlying voices, the core arguments can

Table 3 Interpretation of how NEAT texts were produced and distributed

\begin{tabular}{ll}
\hline Chosun Ilbo & Hankyoreh \\
\hline 1. Supply needs to meet demand & 1. Pursue greater benefit for lower cost \\
2. Government should intervene in the test market & 2. Stabilize public school for students \\
3. One test should be substituted for another: difficult & \\
and easy CSAT, foreign (TOEFL), and domestic (NEAT) & \\
\hline
\end{tabular}


be grouped into a few (explicitly streamlined) representative voices. Social agents were encouraged to take certain actions and rationalize them within the context of takenfor-granted beliefs. Therefore, ascertaining discursive practice enables the social process manifest in textual production, its formulation, and articulation to be traced (Olssen et al., 2004, p. 4). Textual analysis at the stage of description was framed into higher discourses, which are interpreted here. The discursive practices of the two newspapers are summarized in Table 3.

\section{Chosun Ilbo}

The meso-level or "level of discursive practice" involves interpreting specific issues of production and consumption. For instance, it questions how and through what practices Chosun Ilbo consistently produces certain texts (e.g., by market principles) and who the target audience is (e.g., test users as customers). Three interpretations were given to the situational and intertextual contexts of NEAT reportage in Chosun Ilbo: (1) supply needs to meet demand, (2) the government should intervene in the test market, and (3) the test should be replaced to solve the test-driven problem.

Beginning with the first interpretation, Chosun Ilbo adopted the context of the "TOEFL crisis" as a mismatch between supply and demand. High value was often placed on market principles. Moreover, although Chosun Ilbo pursues a small government, it also insists on government intervention in the market when necessary. NEAT was discursively practiced (government intervention was called for) because the current market of testing and being tested was in crisis. Lastly, Chosun Ilbo sustained the belief that test-driven (language education) policy would succeed by replacing one test with another. Thus, TOEFL was identified as the crisis, NEAT as the solution, and easy CSAT as an alternative. The rationale for changing from foreign to domestic tests, and from one domestic test to another, was reiterated through the use of evaluation as a market-driven practice.

\section{Hankyoreh}

Hankyoreh, with its progressive ideological orientation, highlighted two issues: pursuing benefit for lower costs and stabilizing public education for students. These two interpretations were given as situational and intertextual contexts when Hankyoreh selected the article texts on NEAT.

First, benefit-cost texts were selected by Hankyoreh in a consistent way. It highlighted the issues of inconvenience, such as the test registration fees students had to pay. In the TOEFL crisis, it criticized the TOEFL-iBT for not being cost-effective, especially for students preparing for university in Korea, and that a domestic standardized test was called for from the perspective of cost-effectiveness. Unlike Chosun Ilbo's highlighting of the monetary inconvenience-such as students going on TOEFL expeditions and trading seats on the black market-Hankyoreh focused on the cost of test prep related to household expenditure and the national budget loss from NEAT implementation. For Hankyoreh, reducing private education fees was also an important issue.

Moreover, Hankyoreh emphasized the normalization of public education by making an issue of the inconvenience to students in testing contexts, by devaluing the presence of foreign tests of English, and by criticizing the side-effects of the newly developed 
test. Test-taking students were cited as the primary victims of the frequent changes in the high-stakes testing policy. In the creation period, Hankyoreh criticized the hegemonic power of English in Korean society, whereby English test scores secure entrance to more prestigious schools and companies, and people are driven to prepare for highstakes English tests (“Te-nun pang-chi-hal,", 2007; K. Kim, 2007a, 2007b; K. Kim \& W. Lee, 2007). While Hankyoreh succeeded in pointing out students' subordination to high-stakes testing of English, it failed to maintain its critical stance to produce alternative discourses beyond testing and being tested. It asked for domestic and localized tests as a solution to alleviate the reliance on foreign high-stakes testing.

\section{Explanation of socio-political practice}

The underlying ideologies that were taken for granted and moved the NEAT discourses in the two selected newspapers were summarized here. At the explanation stage, the underlying ideologies were scrutinized to ascertain the inveterate beliefs perpetuating, reproducing, and justifying the taken-for-granted orders of discourse. The socio-political practices of the two newspapers can be explained by the ideologies of neoliberal marketization (Harvey, 2005) and evaluative state (Neave, 1998), which represented and justified a state's testing regime in the media through an understanding of neoliberalism.

Chosun Ilbo's ideological orientation places great emphasis on the free market principles, where education also operates under the system of supply and demand. Chosun Ilbo's rationale behind the struggle to introduce, develop, and abolish NEAT can be framed in terms of free competition, high demand, and education as a commodity. NEAT-based reform issues were based on neoliberal educational policy, as different stakeholders in testing, including students and teachers, were characterized as neoliberal entrepreneurs and consumers. Chosun Ilbo aggressively pushed for market-based reform of education, through implementation of NEAT, and one editorial (I.-H. Lee, 2008) clearly illustrated its ideological stance: "Although it inevitably involves fierce objection from anachronistic equalitarian and collective stance, one person should stand up to carry out drastic reform, and I look forward to President-elect Lee putting this into practice."

Another explanation relates to the ideology of the evaluative state (Neave, 1998), in which the state often uses systematic technologies of evaluation as a tool of neoliberal governance. Giannone (2016, p. 500) defines the evaluative state as follows: "variegated forms of evaluation are implemented by each state in order to introduce market rationality in non-economic domains, such as education and health system." Neoliberal values such as competition and entrepreneurship have been often imposed on students through different forms of English language proficiency testing in Korea.

Following the TOEFL crisis, TOEFL was replaced with NEAT, on its prestige footing as a homegrown English test; however, when NEAT's implementation remained uncertain, and it was finally decided that it would not become the CSAT substitute, it was quickly replaced with the "easy CSAT." The underlying assumption of Chosun Ilbo regarding testing culture, therefore, was seen to be determined by its contribution to the struggle to maintain the power of the neoliberal evaluative state (Shin, 2019; Im et al., 2020). Once test-users had to choose between two tests, they could hardly doubt which test was better, or whether a test was necessary: rather, what mattered was being tested. 
Moreover, there followed "incentives for compliance, material and symbolic rewards for success" (Giannone, 2016, p. 506) from the state according to their performance. The state's testing regime reinforces what the state authorizes as legitimate knowledge, while the test determines what is to be learned in class (Shohamy, 2001) and trains students to be the neoliberal entrepreneurs themselves in order to become competitive.

In Hankyoreh, the discourse around neoliberal and evaluative state perspectives was also embedded in articles on benefit-cost effectiveness, victimized students, and the normalization of schools. As Hankyoreh is ideologically orientated toward promoting the public interest, it stood against the wasting of money on test registration or development and emphasized, as a solution, better schemes of testing for public education, such as different (localized) test use. Hankyoreh adopted a reactive rather than a proactive stance on the development and implementation of NEAT, thus failing to elaborate on the competing ideologies that explicitly oppose high-stakes testing regimes or contemporary English language teaching. The dominant culture of high-stakes testing does not allow test-users to reflect on the meaningfulness of their own language learning or test preparation (Freedman, 1995; Menken, 2008). The language locked in teach-to-the-test contexts is often inappropriate and authoritative. It is significantly manipulated, simplified, and even distorted from the way real language is used and acquired (Milroy \& Milroy, 1999; Shohamy, 2006). Hankyoreh anticipated (S. Lee, 2008 February 13; J. Lee \& M. Jeon, 2008) that any test would likely place an additional burden on parents and students but maintained the high-stakes status of English tests.

Neoliberal principles have been embedded everywhere in language policy and planning in Korea (Park, 2016; Piller \& Cho, 2013), and the media discourse of NEAT was primarily driven by the neoliberalism as language policy (Shin, 2019). Taking competitiveness and economic efficiency as its core value, the newly developed standardized test heralded speaking and writing proficiency as a relevant construct, thereby legitimizing the replacement and accelerating state-regulated competition. The idea of an evaluative state that applies the market principle in public education evidently influenced NEAT reportage. The state involved itself in the test market to meet demand under the name of accountability by supplying an alternative, homegrown standardized English proficiency test.

Within the politicized media discourse, students' English competence has been understood as a quantifiable entity or a technicized skill (Bernstein, Hellmich, Katznelson, Shin, \& Vinall, 2015; Park, 2015), which enabled a newly standardized and commodified high-stakes test such as NEAT to be developed and implemented. Additionally, high-stakes testing is an attractive mechanism for making governable subjects (Graham \& Neu, 2004) as neoliberal goals and priorities become embedded in the education market. The test transforms students into quantifiable human capital, making "the neoliberal project of the self is endless, as the skills to be attained are not the true aim: the project itself is" (Bernstein et al., 2015, p. 11). In this study, the media pressured teachers, parents, and students to quickly conform to the newly developed high-stakes test, which the administrators dubbed the positive washback effect. The discourse of commodification and commercialization would encourage individuals to bring forth their adaptive capacity and would lead to a "depoliticizing" of their actions (Giannone, 2016). 


\section{Conclusions}

This paper has examined the discursive struggles related to a newly developed and suspended English test, NEAT, as constructed by the media, and has revealed the discursive practice contributing to the production of underlying ideologies. A total of 84 newspaper articles were selected for the three periods of creation, expansion, and extinction. From the creation of NEAT to its demise, there were competing rationales for its development, suspension, and abolition. As the test was abolished not only by the struggle for hegemony by means of discursive conflicts but also by the abrupt policy change, this study investigated the underlying orientations of each newspaper.

Some might question the usefulness of this study, which analyzes the media discourse on an already vanished test; however, this study aims to raise critical awareness of media discourses and to cast doubt on taken-for-granted beliefs about market- and test-driven policy reforms that are deeply entrenched in society. When they are once again planned and enforced, alternative discourses need to be explored in the media. For example, stateled tests of language proficiency can serve as a bulwark against legitimizing the neoliberalization of the state, helping stakeholders make meaningful decisions about how the test is used. An opt-out, allowing students and teachers to refuse testing, could also be considered. Test overuse and misuse, imported tests, and home-made tests could be framed in different terms of social justice and unintended consequence (McNamara \& Roever, 2006; Shohamy, 2007). Further studies of conflicting discourse can be conducted, collecting different agents' voices. Potential sources include the Korean Ministry of Education, public school teachers, students and parents, and the private education industry. Consulting these sources would allow for a better understanding of how diverse stakeholders construct, interpret, and negotiate the media discourse, based on the struggle between different, and often competing, dialectical tensions. Future media will be an intensified site of textual overlap and intermingling of dialectic relations on language proficiency testing as in many realms.

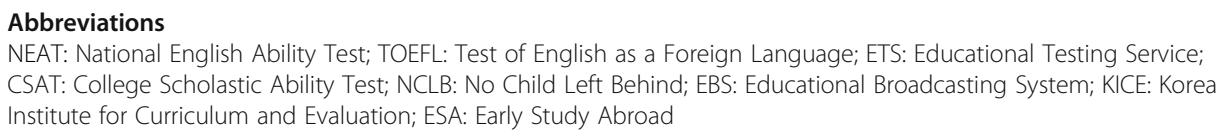

All authors contributed to the whole process through collecting the relevant literature, writing, reviewing, and revising the manuscript. Dongil Shin planned the research design, and Eunhae Cho collected the data and previous literature. Dongil Shin was also a major contributor in revising the first data analysis and completing the manuscript. The authors read and approved the final manuscript.

Authors' information

DS is a Professor in the Department of English Language and Literature at Chung-Ang University, Seoul, Korea. After completing his doctorate degree at University of Illinois at Urbana-Champaign, he has taught and researched (multi)lingual societies, (critical) discourse analysis, language testing (policy), language ideologies, and identities, mostly in Korean contexts.

EC is a Ph.D. student in the Department of Applied Linguistics at Pennsylvania State University. Her current research interests include critical approaches to discourse analysis, language testing (policy), and translingual practice.

Funding

Not applicable 


\section{Competing interests}

The authors declare that they have no competing interests.

\section{Author details}

${ }^{1}$ Department of English Language and Literature, Chung-Ang University, 221 Hukeok-dong, Seoul 156-756, South Korea. ${ }^{2}$ Department of Applied Linguistics, The Pennsylvania State University, State College, PA, USA.

Received: 4 December 2019 Accepted: 20 April 2020

Published online: 16 June 2020

\section{References}

Ahn, S. (2010, January 8a). Han-kwuk-hyeng tho-phul' 2013hak-nyen tay-ip cen-hyeng-ca-lyo hwal-yong. [Using 'Korean TOEFL' for 2013 College entrance data]. Chosun Ilbo, Retrieved from https://m.chosun.com/svc/article.html?sname= news\&contid=2010010701782

Ahn, S. (2010, August 20b). Yeng-e-mwun-cey cel-pan, tut-ki-phyeng-ka-lo chwul-cey hyang-hwu 'han-kwuk-hyeng thophul'lo tay-chey kem-tho [Half of the English questions, to be listening comprehension. Also reviewing 'Korean TOEFL' as an alternative]. Chosun Ilbo, Retrieved from https://news.chosun.com/site/data/html_dir/2010/08/20/2010082000159.html

Ahn, S. (2013, August 28). Swu-cwun-pyel swu-nung ttak 1 nyen ha-ko phyey-ci-ss cen-ceng-pwu ip-si-ceng-chayk cwul-cwulci-wu-ki [After just one year of level based CSAT... former government's admission policies are eliminated in series]. Chosun Ilbo, Retrieved from https://news.chosun.com/site/data/html_dir/2013/08/28/2013082800201.html

Ahn, S. (2014, January 16a). Ko-kyo-yong 'han-kwuk-hyeng tho-phul' ney-pen po-ko kkuth... 371ek nal-lye ['Korean TOEFL' for high school was used four times and abolished. 37.1 billion disappeared]. Chosun I/bo, Retrieved from https://news. chosun.com/site/data/html_dir/2014/01/16/2014011600226.html

Ahn, S. (2014, September 26b). Nel-ttwi-nun yeng-e kyo-yuk [English education running amok]. Chosun I/bo, Retrieved from http://premium.chosun.com/site/data/html_dir/2014/09/25/2014092505202.html

Ball, S. (1993). What is policy? Texts, trajectories and toolboxes. Discourse: Studies in the Cultural Politics of Education, 13(2), 10-17.

Bernstein, K., Hellmich, E., Katznelson, N., Shin, J., \& Vinall, K. (2015). Critical perspectives on neoliberalism in second/foreign language education. L2 Journal, 7(3), 3-14.

Blackledge, A. (2005). Discourse and power in a multilingual world. Amsterdam, Netherlands: John Benjamins Publishing.

Cha, K.W. (2013, March 11). Kwuk-ka-yeng-e-nung-lyek-phyeng-ka kkok si-hayng-tway-ya [lt is necessary to launch NEAT]. Chosun Ilbo, Retrieved from https://news.chosun.com/site/data/html_dir/2013/03/10/2013031001289.html

Cheng, L., \& Curtis, A. (2004). Washback or backwash: a review of the impact of testing on teaching and learning. In L. Cheng, Y. Watanabe, \& A. Curtis (Eds.), Washback in language testing: Research contexts and methods (pp. 3-17). Mahwah: Lawrence Erlbaum.

Cho, C. (2010, December 13). 76ka-ci yu-hyeng pa-thang-u-lo NEAT cek-cwung-lyul 90\% yey-sang [Based on 76 types of test, forecasting the trend of test items with the accuracy of 90\%]. Chosun Ilbo, Retrieved from https://news.chosun.com/site/ data/html_dir/2010/12/12/2010121200678.html

Cho, C. (2011, March 3). Phyo-hyen cwung-sim kyo-yuk-u-lo kul-lo-pel li-te yang-seng [Focusing on expression centered education, global leader training]. Chosun Ilbo, Retrieved from http://edu.chosun.com/site/data/html_dir/2011/03/10/2 $011031000322 . h t m l$

Choi, H. (2007, July 31). Tho-ik-ps-tho-phul tay-chey-hal kwuk-ka-si-hem to-ip [Introduction of National exam to replace TOEIC and TOEFL]. Hankyoreh, Retrieved from http://www.hani.co.kr/arti/society/schooling/225720.html

Choi, M. (2012, March 5). "Ni-thu-nun swi-wun si-hem-ps-ps-ps sa-kyo-yuk manh-i hal-swu-lok pwul-li" [NEAT is an easy test, it is disadvantageous for test takers to get private education]. Chosun I/bo, Retrieved from https://news.chosun.com/site/ data/html_dir/2012/03/04/2012030400530.html

Chung, S. (2007, April 16). 7wel tho-phul' cep-swu han-kwuk-man cey-oy [Only Korea is excluded for the registration of 'TOEFLs on July']. Chosun Ilbo, Retrieved from https://news.chosun.com/site/data/html_dir/2007/04/16/2007041600063.html

Crawford, J. (2004). Educating English learners: language diversity in the classroom. Los Angeles: Bilingual Educational Services.

DiGiacomo, S. M. (1999). Language ideological debates in an Olympic city. In J. Blommaert (Ed.), Language ideological debates (pp. 105-142). Berlin: Mouton de Gruyter.

Eum, S., \& Kim, J. (2013, August 28). 'Swu-cwun-pyel swu-nung'-'ni-thu yen-kyey'-phyey-ci-ss-col-sok 'payk-nyen-tay-kyey'-ey hon-lan pan-pok [Abolition of 'differentiated KSAT' which is 'related to NEAT'...a rough-and-ready 'a farsighted national policy' results in repeated confusion]. Hankyoreh, Retrieved from http://www.hani.co.kr/arti/society/schooling/601116.html

Fairclough, N. (1992). Discourse and social change. London: Polity Press.

Fairclough, N. (2003). Analysing discourse: textual analysis for social research. London: Routledge.

Foucault, M. (1981). The order of discourse. Trans. lan McLeod. In R. Young (Ed.), Untying the text: A post-structuralist reader (pp. 48-78). Boston: Routledge.

Freedman, W. (1995). Exam-based reform stifles student writing in the U.K. Educational Leadership, 52(6), 26-29.

Giannone, D. (2016). Neoliberalization by evaluation: explaining the making of the neoliberal evaluative state. Partecipazione $e$ Conflitto, 9(2), 495-516.

Graham, C., \& Neu, D. (2004). Standardized testing and the construction of governable persons. Journal of Curriculum Studies, 36(3), 295-319.

Halliday, M., \& Matthiessen, C. (2014). Halliday's introduction to functional grammar. London: Routledge.

Han-kwuk-hyeng tho-phul phyey-ci, kyo-yuk-pwu pyen-tek en-cey-kka-ci cham-a-ya ha-na ['Korean TOEFL' abolished, how long would we endure the whims of the Ministry of Education]. (2014, January 17). Chosun Ilbo. Retrieved from https:// news.chosun.com/site/data/html_dir/2014/01/16/2014011604185.html

Harvey, D. (2005). A brief history of neoliberalism. Oxford: Oxford University Press.

Hong, J. (2007, April 14). Tho-phul tay-lan' i-tay-lo twu-ko pol ken-ka [TOEFL crisis' should we let it happen]. Chosun Ilbo, Retrieved from http://www.ohmynews.com/NWS_Web/Niew/raw_pg.aspx?CNTN_CD=A0000404300

Im, G.-H., Cheng, L., \& Shin, D. (2020). Sociopolitical factors surrounding the rise and demise of the National English Ability Test (NEAT) in South Korea. In S.-A. Mirhosseini \& P. I. De Costa (Eds.), Sociopolitics of English language testing. (pp. 147164). New York, NY: Bloomsbury Publishing. 
Jang, Y. (2008, December 24). 'Kwuk-ka-yeng-e-nung-lyek-phyeng-ka-si-hem'i kan-kwa-han kes [What 'NEAT' overlooked]. Chosun Ilbo, Retrieved from https://news.chosun.com/site/data/html_dir/2008/12/23/2008122301615.html

Jeon, J.-B. (2012, March 19a). "Ccalp-un si-kan-ey ki-swul-man hak-sup-han-ta-nun sayng-kak-un wi-hem-hay" ["It is dangerous to think that you will only pick up the skills in a short period of time"]. Hankyoreh, Retrieved from http://www.hani.co.kr/ arti/society/schooling/524104.html

Jeon, J.-B. (2012, March 19b). Yeng-e-kyo-yuk-ey mol-a-chi-nun kwuk-yeng-si pa-lam [A gust of NEAT on English education]. Hankyoreh, Retrieved from http://www.hani.co.kr/arti/society/schooling/524094.html

Jeon, J.-H. (2007, April 17). E-cey o-hwu-to kkam-ccak cep-swu [Sudden registration yesterday afternoon]. Hankyoreh, Retrieved from http://www.hani.co.kr/arti/society/schooling/203317.html

Jin, M. (2012, February). Co-ki-yu-hak = yeng-e-man-cem he-thun kkwum [Early study abroad = full score in English is a vain hope]. Hankyoreh, Retrieved from http://www.hani.co.kr/arti/society/schooling/518179.html

Johnson, E. (2005). WAR in the media: Metaphors, ideology, and the formation of language policy. Bilingual Research Journal, 29(3), 621-640.

KERIS (Korea Education and Research Information Service). (2013). White paper on ICT in education, Korea. Retrieved from http://english.keris.or.kr/whitepaper/WhitePaper_eng_2013.pdf

Kim, J. (2007, April 13). Tho-ik tho-phul kwang-phwung eps-ay-lye-myen kwuk-ka-cha-wen-se kong-in-si-hem man-tul-e-ya [To get rid of violent gale of TOEIC and TOEFL, it is needed to develop a national standardized test]. Chosun Illbo, Retrived from https://news.chosun.com/site/data/html_dir/2007/04/13/2007041300046.html

Kim, K. (2007, April 17a). Mi 'sen-che'ey wul-ko-wus-nun 'yeng-e-kwang-phwung' ['English frenzy' cries and laughs for America's favorable arrangements]. Hankyoreh, Retrieved from http://www.hani.co.kr/arti/society/society_general/203314.html

Kim, K. (2007, April 17b). Oy-ko-yu-hak cil-cwu-ka 'tho-phul-tay-lan'khi-we [Rush for foreign language high school and study abroad worsened 'Toefl crisis'. Hankyoreh, p. 3.

Kim, K., \& Choi, W. (2007, April 14). Tho-phul 'kal-phang-cil-phang' swu-hem-sayng pwun-thong ['Indecisive' TOEFL, furious test-takers]. Hankyoreh, p. 7.

Kim, K., \& Lee, W. (2007, April 17). Thuk-pyel-si-hem im-si-pang-phyen ss mi-kwuk-tay-hak in-ceng an-hal-swu-to [Special test as temporary measure... American universities might not approve of the result]. Hankyoreh, Retrieved from http:/www. hani.co.kr/arti/society/schooling/203319.html

Kim, M. (2012, April 23). Han kong-kyo-yuk kyo-sa-uy pwu-kku-le-wum [A public teacher's confession]. Chosun Ilbo, Retrieved from https://news.chosun.com/site/data/html_dir/2012/04/22/2012042201672.html

Kim, N. (2007, Aprill 11a). Tho-phul tay-lan' in-the-neys cep-swu ma-pi [TOEFL crisis' Internet reception paralyzed]. Chosun Ilbo, Retrieved from https://news.chosun.com/site/data/html_dir/2007/04/11/2007041100006.html

Kim, N. (2007, April 13b). Tho-phul tay-lan...ETS "7wel si-hem-tung-lok chwi-so" [ETS "no registration for July"]. Chosun Ilbo, Retrieved from https://news.chosun.com/site/data/html_dir/2007/04/13/2007041300045.html

Kim, S. (2011, September 26). Mal-man mwu-seng-han 'NEAT' (kwuk-ka-yeng-e-nung-lyek-phyeng-ka-si-hem) e-tteh-key cwunpi-hal-kka? Kyo-kwa-se-lo ki-pon cap-ko EBS kang-cwa-lo ik-hye-la [How do we prepare for "NEAT," that is all talk? Build up base with textbook and practice with EBS online lecture]. Chosun Ilbo, Retrieved from http://news.chosun.com/site/ data/html_dir/2011/09/25/2011092500687.html

Kim, Y. (2014, January 16). Swu-nung-yeng-e tay-chey-han-ta-te-ni-ss hak-pwu-mo-ps-hak-sayng-tul "hwang-tang-hay" [alledge to replace CSAT... parents and students ridiculed]. Chosun Ilbo, Retrieved from http://news.chosun.com/site/ data/html_dir/2014/01/16/2014011600106.html

Kim, Y., \& Kim, H. (2013, May 13). Han-kwuk-hyeng tho-phul' swu-nung yeng-e tay-chey-han-ta-te-ni... 400ek nal-lil phan [Korean TOEFL alleged to replace CSAT English... about to waste a 40 billion won]. Chosun Ilbo, Retrieved from https:// news.chosun.com/site/data/html_dir/2013/05/13/2013051300107.html

Lee, H. (2013). Chwum-chwu-nun ip-si cey-to-ss hak-sayng-tul-uy mok-so-li-nun eps-ta [No consistency in college entrance system. Students' voice unheard]. Chosun Ilbo, Retrieved from https://news.chosun.com/site/data/html_dir/2013/09/05/2 013090504369.html

Lee, H., \& Lee, K. (2016). An analysis of the failure(s) of South Korea's National English Ability Test. Asia-Pacific Education Researcher, 25(5-6), 827-834

Lee, I.-H. (2008). Yeng-e-kyo-yuk payk-nyen-tay-kyey-lul [Considering English as one of the far-sighted national policies]. Chosul llbo, Retrieved from https://news.chosun.com/site/data/html_dir/2008/01/18/2008011801057.html

Lee, J. (2008, December 19). Han-kwuk-hyeng tho-phul' 2012nyen si-hayng ['Korean style TOEFL' will launch in 2012]. Hankyoreh, Retrieved from http://www.hani.co.kr/arti/society/schooling/328514.html

Lee, J. (2010). Ideologies of English in the South Korean "English immersion" debate. In M. T. Prior, Y. Watanabe, \& S.-K. Lee (Eds.), Selected proceedings of the 2008 Second Language Research Forum: exploring SLA perspectives, positions, and practices (pp. 246-260). Somerville: Cascadilla Proceedings Project.

Lee, J. (2011, May 27). Swu-nung-yeng-e tay-chey hwak-ceng-an-tway swu-hem-sayng i-cwung-ko [Replacement of CSAT English undecided, test-takers trapped in 'double whammy']. Hankyoreh, Retrieved from http://www.hani.co.kr/arti/ society/schooling/479959.html

Lee, J., \& Jeon, M. (2008, December 19). Cwung-ps-ko-sayng-to 1 kup ung-si ka-nung-ps-ps-ps-sa-kyo-yuk pwu-chay-cil [allowing middle school and high school students to take level 1... instigating private education]. Hankyoreh, Retrieved from http://www.hani.co.kr/arti/politics/politics_general/328536.html

Lee, S. (2008, February 13). "Thuk-mok-ko tay-hak yeng-e-sen-pal-pang-sik cey-han-hay-ya" ["We need to limit the methods of the entrance exam for special-purpose high schools"]. Hankyoreh, Retrieved from http://www.hani.co.kr/arti/society/ schooling/269143.html

Lee, Y. (2007, May 14). Yeng-mi-kwen tay-han cin-hak wen-ha-myen tho-phul cwun-pi-hay-ya [lf you want to go to the U.S., you should prepare for TOEFL]. Chosun Ilbo, Retrieved from https:/news.chosun.com/site/data/html_dir/2007/05/13/2 007051300409.html

Lin, A. (2014). Critical discourse analysis in applied linguistics: a methodological review. Annual Review of Applied Linquistics, 34, 213-232.

Madaus, G., \& Russell, M. (2010). Paradoxes of high-stakes testing. The Journal of Education, 190(1/2), 21-30.

McDonald, L. (2014). Think tanks and the media: how the conservative movement gained entry into the education policy arena. Education Policy, 28(6), 845-880. 
McNamara, T., \& Roever, C. (2006). Lanquage testing: the social dimension. London: Longman.

Menken, K. (2008). English learners left behind: standardized testing as language policy. Clevedon: Multilingual Matters.

Milroy, J., \& Milroy, L. (1999). Authority in language: investigating standard English. New York: Routledge.

Neave, G. (1998). The evaluative state reconsidered. European Journal of Education, 33(3), 265-284.

Oktar, L. (2001). The ideological organization of representational processes in the presentation of us and them. Discourse and Society, 12(3), 313-346.

Olssen, M., Codd, J., \& O'Neill, A.-M. (2004). Education policy: globalization, citizenship and democracy. London: Sage.

Park, J. S-Y. (2016). Language as pure potential. Journal of Multilingual and Multicultural Development, 5(37), 453-466, https:/ doi.org/10.1080/01434632.2015.1071824.

Park, J. S.-Y. (2010). Naturalization of competence and the neoliberal subject: success stories of English language learning in the Korean conservative press. Journal of Linguistic Anthropology, 20(1), 22-38.

Piller, I., \& Cho, J. (2013). Neoliberalism as language policy. Language in Society, 42(1), 23-44.

Ryu, J. (2008). Tut-ki-ilk-ki pi-cwung-ss kyo-yuk-kwa-ceng nay chwul-cey tung-kup-cey sil-si, yeng-e tok-se manh-i hay-ya [Listening and reading weight... Enforcement of the grading system of the subject in the curriculum, extensive English reading will be required]. Chosun Ilbo, Retrieved from http://news.chosun.com/site/data/html_dir/2008/01/27/2008012 700689.html

Shin, D. (2012). Analyzing newspaper articles on 'TOEFL Crisis' through critical discourse analysis. Foreign Languages Education, $19(1), 187-210$

Shin, D. (2019). Analyzing media discourse on the development of the National English Ability Test (NEAT) in South Korea. Language Testing in Asia, 9(4), https://doi.org/10.1186/s40468-019-0081-z.

Shohamy, E. (2001). The power of tests: A critical perspective on the use of language tests. London: Longman.

Shohamy, E. (2003). The issue: Implications of language education policies for language study in schools and universities. Modern Language Journal, 88(2), 277-286.

Shohamy, E. (2006). Language policy: Hidden agendas and new approaches. Abingdon: Routledge.

Shohamy, E. (2007). Language tests as language policy tools. Assessment in Education, 14(1), 117-130.

Te-nun pang-chi-hal swu eps-nun ci-kyeng-ey i-lun 'tho-phul tay-lan' [TOEFL crisis' has reached a point where it cannot be left unattended anymore]. (2007, April 14). Hankyoreh. Retrieved from http://www.hani.co.kr/arti/opinion/editorial/202 882.html

Van Dijk, T. A. (1998). Opinions and ideologies in the press. In A. Bell \& P. Garrett (Eds.), Approaches to media discourse (pp. 21-63). Oxford: Blackwell.

Van Dijk, T. A. (2009). Critical discourse studies: A sociocognitive approach. In R. Wodak \& M. Meyer (Eds.), Methods for critical discourse analysis (pp. 62-86). London: Sage.

Whitehead, G. (2016). The rise and fall of the National English Ability Test: Exploring the perspectives of Korean high school English teachers. Asian EFL Journal, 18(4), 124-155.

Wodak, R. (2000). From conflict to consensus? The co-construction of a policy paper. In P. Muntigl, G. Weiss, \& R. Wodak (Eds. ). European Union discourses on un/employment: An interdisciplinary approach to employment policy-making and organizational change (pp. 73-114). Amsterdam: John Benjamins.

Won, J. (2007, April 20). Tho-phul-i mwu-es-i-kil-lay ss han-kwuk-se-man 'nan-li'in-ka? [What is TOEFL? Is it a 'crisis' only in Korea?]. Chosun Ilbo, Retrieved from https://news.chosun.com/site/data/html_dir/2007/04/20/2007042000778.html

Yoo, S. (2009, January 22). Cwung-ko-kyo yeng-e-seng-cek mal-ha-ki 10\% pan-yeng [Secondary schools' English score reflects only $10 \%$ of speaking ability]. Hankyoreh, Retrieved from http://www.hani.co.kr/arti/society/schooling/334678.html

Yoo, S. (2011, October 4). Co-ki-yu-hak pa-lam ta-si sol-sol [Early study abroad is on the rise]. Chosun Ilbo, Retrieved from https://news.chosun.com/site/data/html_dir/2011/10/04/2011100400101.html

\section{Publisher's Note}

Springer Nature remains neutral with regard to jurisdictional claims in published maps and institutional affiliations.

\section{Submit your manuscript to a SpringerOpen ${ }^{\circ}$ journal and benefit from:}

- Convenient online submission

- Rigorous peer review

Open access: articles freely available online

High visibility within the field

- Retaining the copyright to your article

Submit your next manuscript at $\boldsymbol{\nabla}$ springeropen.com 